\author{
AMBROSE IGBOKE, \\ University of Nigeria (Nsukka, Nigeria) \\ e-mail: ambigon2001@yahoo.com,ORCID 0000-0001-6377-8774
}

\title{
ENHANCING NATIONAL SECURITY THROUGH INTERNET BROADCASTING: BENEFITS AND LIMITATIONS
}

The article is dedicated to the evaluation of the potential of Internet Broadcasting for the strengthening the national security system of the state. The importance of this problem is caused by the security priorities, which the stability of the political system of the state, life, health and welfare of the nation depend on. The author makes his theoretical conclusions on the basis of an empirical research conducted in three regions of Nigeria. This African country has many national security issues: religious conflicts, terrorism, banditry, kidnapping, separatism, including the Biafra Sovereign Movement in the Southeast, "Boko Haram" activity in the north and Niger Delta fighters, as well as starvation, impoverishment, communal strife, conflict between pastoralists and farmers, the weakness of the federal government, lack of medical services, unemployment and so forth. The hypothesis is that Internet broadcasting significantly contributes to the solving of these problems. Scientific tasks that are accomplished in the research are: a) determining of the extent to which Internet broadcasting can enhance national security in Nigeria; b) ascertain the benefits and c) investigate the limitations of using the Internet broadcasting for solving national security problems. A sample of 384 was drawn from three states of Enugu, Abia and Anambra through a multi-stage sampling technique. In the analysis of data for the study, SPSS version 22 was used while simple percentages, mean and standard deviation were used as statistical tools. The result of this study showed that $52 \%$ of the respondents reported that Internet broadcasting can promote national security to a large extent. The respondents mentioned better speed, accessibility, a wider reach than TV, usability as benefits of Internet broadcasting. On the other hand, the limitations of the Internet broadcasting are: Internet broadcasting cannot be accessed by people without Internet skills; expensive gadgets needed for access; relatively short term of gadget's power etc. Analyzing conclusions of the research, the author reflects on the Technological Determinism theory, Safe Nigeria model and Nigeria's national security objectives. Practical recommendations about the improvement of the national security system of Nigeria through the creation of conducive environment for Internet broadcasting are given.

Keywords: benefit; limitations; Internet Broadcasting; National Security; Nigeria.

\section{INTRODUCTION}

The security of lives and property is one of the fundamental challenges facing countries, regions and continents. This partly explains why most countries make the security of lives and property of their citizens a foremost responsibility for their governments. In Nigeria, provision of Section 14.-(1b) of the 1999 Constitution (as amended) states that the security and welfare of the people shall be the primary purpose of government. This suggests that it is the responsibility of the government to protect its citizens and their property. The United Nations (1948) Universal Declaration of Human Rights also recognizes the importance of security as a basic right that must not be taken away from all human beings. This is contained in articles 3, 22 and 25(1) respectively. While article 3 posits that everyone is entitled to right to life, liberty and security, article 22 notes that every member of society is entitled to social security and has the right to achieve this via national effort and international co-operation, based on the organization and resources of each State. Article 25 (1) states that everyone has the right to a standard of living that is good enough for the health and well-being of himself and of his family, which also covers food, clothing, housing and medical care and necessary social services, and the right to security in case of unemployment, sickness, disability, widowhood, old age or other lack of livelihood that he/she may not be able to handle unassisted.

Nigeria, being a member of the United Nations, is obliged to implement these statutes. By implication also, this underscores the importance of security to every nation. The government of Nigeria, in recognition of the prime place of national security, placed it under the exclusive list, hence, only the Federal Government controls the security architecture of Nigeria.

Thus, the heads of security agencies; the Army, Navy, Air force and the Police (commonly called service Chiefs) are appointed by and also answerable to the President and Commander in-Chief of the Federal Republic of Nigeria.

National security describes all the issues relating to the security of lives and property of a country. However, this does not imply the state of being safe and the absence of fear, anxiety and danger. D. Asad (2007) corroborates that national security cannot be narrowed down to exclusively military term, socio economic and cultural aspects but that problems of development and modernization, and national 
integration should be deemed important in considering a country's national security. J. I. Ebeh (2015) notes that national security question covers many issues relating to human existence. According Ebeh, the best way to approach it is from the systems theory perspective where a dislocation in any particular area of the system is bound to have an overlapping effect on other areas that span from food security to issues of environmental degradation, to health matters, among others:

A number of factors may expose a nation to danger. To that extent, national security may also be viewed as a multidimensional process whose purpose is to safeguard national values. The most fundamental values of any nation are its survival, self-preservation, and self-perpetuation. A nation that is capable of protecting herself from harm equally enjoys immense capacity for enviable development. (Ibid: 5)

From the above discussion, it is evident that the concept of national security can best be explained than defined. E. Oshio (2009) affirms that national security does not appear to lend itself to any precise definition, partly because, the nature and concept of national security may vary from one State to the other and that the concept contains an ideological element which renders empirical evidence irrelevant as a means of resolving the debate. Oshio, nonetheless, provides two main tendencies in defining national security as: first, state centered concept which views national security in terms of defence and survival of the State and the second involves the factoring of the State and the individual into the constituents of the definition. According to this definition, security involves freedom from danger or threat to a nation's ability to protect and develop itself, promote its cherished values and wellbeing of its people. For this study, the researcher operationalized national security as all issues relating to safety, and socio-economic wellbeing of a nation. This covers issues of conflict, war, poverty, health and hunger.

This definition, though broad, suggests that the media have roles to play in national security either in the area of security awareness, health education, hunger eradication, poverty reduction and other indicators which engender or endanger national security. The broadcast media, known for their immediacy, are usually thought to be very efficient in such efforts at making life better for the society. This expectation is even higher considering the revolution in technology that has led to the emergence of Internet broadcasting also called webcasting.
Internet broadcasting is a concept that describes the planning, process and broadcasting of broadcasting through the Internet. Internet broadcasting is done is such a way that conventional broadcast media stream live on the Internet while at the same time reaching out to their receivers through their conventional gadgets like radio or TV. There are also some stations that are strictly Internet based. For example in Nigeria, the Nigerian Television Authority Streams live at: http://www.nta.ng/live/ the African Independent Television streams live at: $h$ ttp://www.aitonline.tv/live Channels TV streams live at: http://www.channelstv.com/live/, Television Continental streams live on www.tvcnews.tv/live, while the Federal Radio Corporation of Nigeria streams live at: http://ww2.radionigeria.gov.ng/ home2.php among several others. These stations, in addition to reaching their audiences through their conventional terrestrial and cable channels, they also broadcast simultaneously via the Internet. There are some television transmissions in Nigeria that are solely on the internet, examples are tv360 Nigeria (www.tv360nigeria.com), Guardian TV (m.tv.guardian.ng), Oak TV (www.oak.tv), Linda Ikeji TV (www.lindaikeji.tv), Iroko tv (www.irokotv.com) and many more. Broadcasting through the Internet offers unique advantages because the audience, who are outside the terrestrial transmitting reach of a particular broadcast medium, can have access to its broadcast messages, even without a TV set and through smart televisions.

The emergence of social media as a result of web 2.0 has also aided Internet broadcasting. Social media platforms like YouTube, Facebook, Instagram and Twitter provide fertile grounds for Internet broadcasting to strive. This is because; broadcast stations and individuals can upload some of their contents via these channels for the consumption of the public. Westwater, Ice and Furht (nd) submit that in addition to reprocessed audio or video that is transferred from radio or TV to the Internet, webcasting also means broadcasting new, original content, sometimes live, on the Web. Westwater et al list the technology for the Internet broadcasting thus: IP Simulcast - a new Internet broadcast protocol, which provides inexpensive, efficient, and reliable audio and video broadcasting and new audio and video compression algorithms, which allow real-time audio and video transmission of data at very low bit rates (1/3 of the modem bit rate) and with high quality. Rohde and Schwarz (2001) provide a diagrammatical explanation of the convergence of the Internet and broadcasting thus:

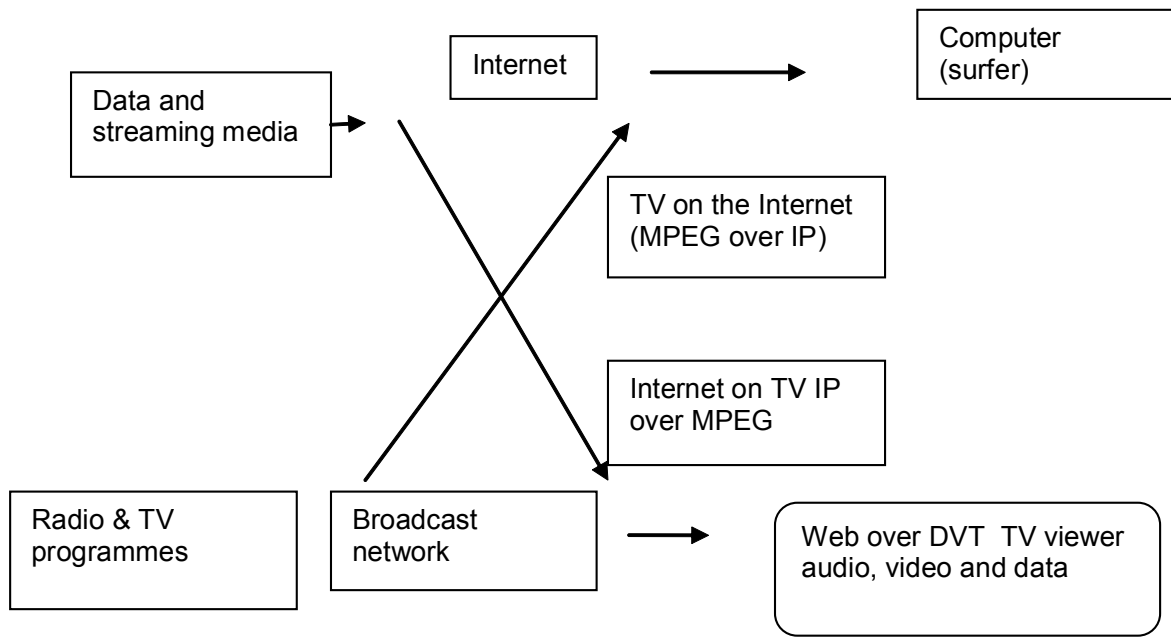

Figure 1. Internet broadcasting process 
The diagram above shows the internet broadcasting process. It clearly indicates the convergence between the Internet and broadcasting. In contemporary Internet broadcasting, questions arise as to its relevance in solving societal issues like national security. It is against this premise that this study investigated the place of Internet broadcasting in addressing issues of national security in Nigeria.

\section{Statement of the problem}

The revolution in technology which has given rise to Internet broadcasting has posed a challenge to contemporary researchers in a bid to explore and explain the importance of this new broadcasting pattern with regards to addressing critical societal issues like national security. Although previous studies that have attempted to investigate the nexus between the media and national security abound and tend to report very little conflicting accounts, not much has been done with regards to Internet broadcasting. The increasing access and use of the Internet coupled with the awful statistics relating to Nigeria's national security makes studies in this regard desirous. This situation, apart from creating a gap in the literature, challenges the thinking of researchers who are interested in studying the media-society link. It is on the strength of this reality, that this study is situated.

\section{Research objectives}

The general objective of this study is to find out the role of Internet broadcasting in addressing national security issues in Nigeria. Specifically, the study seeks to:

1. Determine the extent to which Internet broadcasting can enhance national security in Nigeria.

2. Ascertain the benefits of using Internet broadcasting for national security in Nigeria.

3 . Investigate the limitations of using the Internet broadcasting for national security in Nigeria.

\section{Research questions}

This study sought answers to the following questions:

1. To what extent can Internet broadcasting enhance national security in Nigeria?

2. What are the benefits of using Internet broadcasting for national security in Nigeria?

3. What are the limitations of using Internet broadcasting for national security in Nigeria?

\section{Literature review}

\section{Nigeria's National Security in Perspective}

Nigeria has had many challenges that fall within the operational definition of national security. These challenges include: communal clashes, religious conflicts, terrorism, banditry, Movement for the Sovereign State of Biafra (MOSSOB) in the South East, Boko Haram in the North, Niger Delta Militancy in the Niger Delta, herdsmen-farmer conflicts, kidnapping, hunger, increasing poverty rate, lack of power and health care services, unemployment, among several others. These and many more have posed serious challenges to successive governments in Nigeria.

Another security threat in Nigeria today is the conflict between farmers and Fulani herdsmen. Gever (2014) regretted that conflicts of varying degrees between farmers and herdsmen have become too perennial in Nigeria. And that these conflicts sometimes end fatally for both parties, properties worth billions are destroyed, people are displaced from their homes, cattle are killed among others.

Apart from the human security, the issue of social security is equally very essential. In this regards, Oyebade
(2014) observes that social security such as job availability, good education, good health care services, poverty reduction, among others are very central to national security. In recognition of the importance of social security, the Universal Declaration of Human Rights (1948) in article 25(1) proclaims that everyone is entitled to a standard of living good enough for the health and well being of himself and of his family; which include food, clothing, housing and medical care and necessary social services, and the right to security in case of unemployment,sickness, disability, widowhood, old age or other lack of livelihood in circumstances beyond his control. The Human Rights Watch (2014) links social security with human security. It adds that when people are hungry, lack basic education, affordable health care services and many other social needs of life, they are likely to constitute security threat to their environments.

\section{Review of Empirical Studies}

In this segment, the researcher reviewed previous empirical studies that are related to the current one. First, the researcher reviewed a study conducted by Gever (2016) on 'Questioning the Safe School Initiative and Making a Case for a Safe Nigeria Model: The Media as the Nucleus'. The aim of the study was to find out the role of the media in the attainment of national security. The researcher adopted survey research design to achieve the study aim. Through a purposively sampling technique, 37 respondents were selected for the study. The result of the study showed that there cannot be safe schools in war-like zone. Findings further showed that Nigeria needs is a comprehensive approach that addresses the myriad of challenges facing the country. These challenges were identified to cover the social welfare of Nigerian citizens to strengthening the public institutions to gain public trust. Based on the result of this study, Gever propounded a safe Nigeria model as shown below:

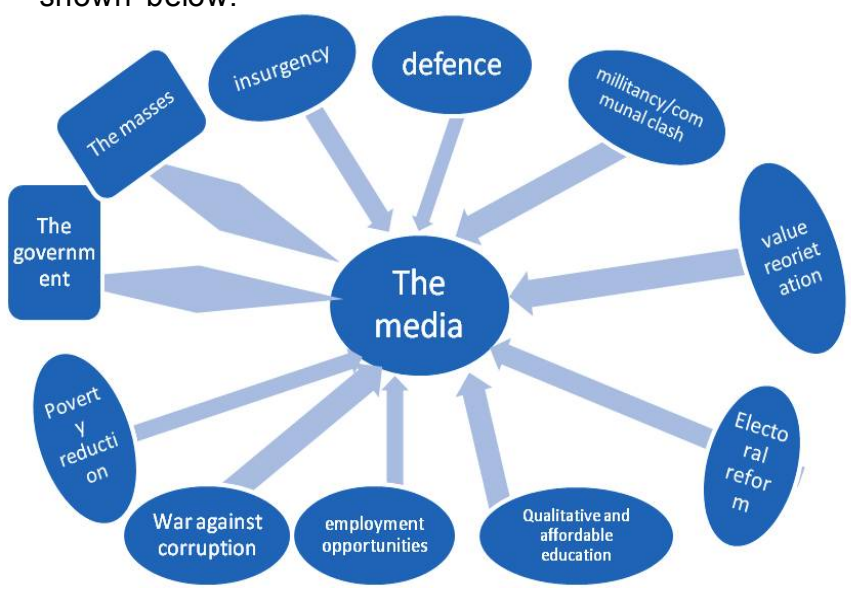

Figure 2: Safe Nigeria Model: Source: Gever 2016

In explaining this model, he opines that the circular model above shows that the media are central to any plan aimed at improving Nigeria. According to this model, the government, Nigerians and the media are supposed to be maintaining frequent communication. The model further espouses that Nigeria's national security will continue to be threatened if issues like the fight against corruption, poverty reduction, unemployment, provision of quality and affordable education, electoral reforms, citizens value reorientation, prevention of insurgency, militancy and communal clashes, are not properly handled. This study is related to the current one because it addresses issues 
bothering on the role of the media in national security. The study, nonetheless, did not examine how Internet broadcasting could be useful in this regard. The current study will fill this gap.

Imoh (2013) did a study on 'Mass Media Management of the Inter-Ethnic Conflict In Warri Delta State, Nigeria: An Evaluative Study'. The general objective of the study was to determine the role played by Delta Broadcasting Service, Warri, in the prevention, resolution and transformation of the Inter-ethnic conflict in Warri in 2003. The researcher adopted survey research design to investigate the subject matter. Purposive sampling was applied to sample two 2 policy and decision makers, 4 producers and 3 programme staff for interview. With the aid of the checklist, relevant data were collected on these variables using individual interviews with the staff and an analysis of the content of programmes aired during the conflict to the general public. The result of the study showed that the Delta Broadcasting Service (DBS) played an active role of information dissemination during the period under study. The researcher documented that through phone-in programmes, people were able to communicate directly with the government of Delta State on issues relating to the conflict.

Giannakos and Vlamos (2013) did a study on 'Educational Webcasts' Acceptance: Empirical Examination and the Role of Experience.' In this study, Giannakos and Vlamos used variables from the Unified Theory of Acceptance and Use of Technology, Social Cognitive Theory and Theory of Planned Behavior as essential predictors of eLearning tools acceptance and to further verify the effect of the selected key variables on webcast acceptance. Giannakos and Vlamos adopted survey research design while through a purposive means, 248 webcast-based learners were used to examine webcasts' adoption and the differences between learners with low and high levels of webcast usage experience. Results showed the effects of the key variables and experience on learners' intention to use webcasts and indicated the moderating effect of learners' experience on the relationships between (1) Perceived Behavioral Control and Behavioral Intention and (2) Social Norm and Behavioral Intention. This study is related to the current one because it examined the influence of webcast (Internet broadcasting) in e-learning. The researcher did not look at webcast in relation to national security. The current study will address this.

\section{Theoretical Framework}

This study used one theory and one model. They are the Technological Determinism Theory and the Safe Nigeria Model. The Technological Determinism (TD), simply put, is the idea that technology has important effects on our lives (McQuail, 2005). The theory was propounded by McLuhan in 1960. McLuhan argues that changes in technology will also affect the generality of the society. This idea features prominently in the popular imagination and political rhetoric, for example, the idea that the Internet is revolutionizing economy and society (McLuhan, 1964). Technological determinism has also had a long and controversial history in the social sciences in general and in organization studies in particular (Asemah, 2011). Critics of technological determinism argue variously that technology itself is socially determined, that technology and social structures co-evolve in a non-deterministic, emergent process, or that the effects of any given technology depend mainly on how it is implemented which is in turn socially determined. This theory is relevant to the current study because it provides the basis for understanding the changes that have led to the emergency of Internet broad- casting, the benefits and limitations of Internet broadcasting. The theory also helps in explaining Internet broadcasting which is a change in the broadcast industry brought by improvement in technology.

\section{METHODS}

This study used descriptive survey method to achieve its aim. This was because survey is normally a suitable method for descriptive, explanatory and exploratory purposes (Babbie, 2013) therefore, hence the study sought to find out the benefits and limitations of the Internet broadcasting, survey was found useful.

\section{Area / Population}

This study was conducted in three states of SouthEastern Nigeria. The States are: Enugu, Abia and Anambra states. The population of this study was all the Internet users in Nigeria. The total population of Internet subscribers in Nigeria, according to Nigerian Communication Commission is 111.6 million as at December, 2018 (Premium Times, 2019).

\section{Sample Size}

The researcher determined the sample size for this study through the Australian Calculator as provided by the National Statistical Service (NNS) was used. The confidence level was $95 \%$ precision level of 0.05 and estimated variance of $5 \%$ will be used.

\section{Sampling Technique}

This study adopted multi-stage sampling technique to achieve its aim. This was to enable the researcher adopt a scientific process in selecting the sample. This process was accomplished using the following stages:

Stage l:

At the first stage of the sampling, the researcher adopted simple random technique to select three states from South- East Nigeria. The states are Enugu, Abia and Anambra.

Stage II:

At the second stage, the researcher considered the three states as clusters. Subsequently, 128 copies of the questionnaire were distributed to each of the three states. This summed up to 384 and 1 questionnaire was left out because the sample size was not even. The researcher decided that 1 copy would be left out because it was insignificant to affect the result of the study. It is important to add here also that all the three states got equal sample size because there was no existing list of the Internet users known to the researcher.

Stage III:

At this stage, the researcher sampled for the individual respondents. Therefore, the questionnaire copies were taken to the various state capitals of the selected areas. The instruments were given to only respondents who admitted that they were Internet users.

\section{Instrument for Data Collection}

A self-developed questionnaire was used to collect data for this study. The questionnaire was developed after a review of literature. The instrument was administered to the respondents with the help of three research assistants who were briefed on the mode of administration. They were also told to administer and collect the instrument immediately to avoid cases of missing copies.

\section{Method of Data Analysis}

In the analysis of data for this study, the researcher used the Statistical Package for Social Sciences (SPSS 
16.0). In terms of statistical tool, the mean and standard deviation were used in the study. The researcher adopted the likert scale ranging from strongly agree to strongly disagree. The bench mark for accepting or rejecting a statement was 3.0 because it was a five-point scale.

\section{RESULTS}

Out of the 384 copies of the questionnaire that were administered, 363 copies were filled and returned and found useful. This represents a returned rate of $94 \%$. This was considered significant for data analysis because the non-returned rate was too small to affect the result of the study.

\section{Sample Attributes}

The demographic attributes of the respondents revealed that $196(54 \%)$ were male while 167 (46\%) were female. The result also showed that $121(33 \%)$ were within the age bracket of $18-24$, and $111,(31 \%)$ were within the age bracket of $25-29$ while $131(36 \%)$ were within the age bracket of 30 and above. Also, 101(28\%) were civil servants,
$103(28 \%)$ business $61(17 \%)$ were public servants while $98(27 \%)$ reported as others.

Table I: The extent to which Internet broadcasting can enhance national security in Nigeria

\begin{tabular}{lll}
\hline Extent & Frequency & Percentages (\%) \\
\hline To a large extent & 191 & 52 \\
To an extent & 104 & 29 \\
To a low extent & 68 & 19 \\
Total & 363 & 100 \\
\hline
\end{tabular}

The result from table I above revealed that most of the respondents $(52 \%)$ reported that Internet broadcasting can promote national security to a large extent while some $(29 \%)$ reported that the Internet broadcasting can promote national security to an extent with few (19\%) reporting that the Internet broadcasting can promote national security to a low extent.

Table II: The benefits of Internet broadcasting to national security $(n=363)$

\begin{tabular}{lccc}
\hline Item & Mean & SD & Decision \\
\hline & & & \\
It is faster & 3.1 & 0.49 & Accepted \\
Many people have access to the Internet than TV & 3.6 & 0.99 & Accepted \\
It can be easily accessed & 2.6 & 0.81 & Accepted \\
It has a wider reach & 2.8 & 0.88 & Accepted \\
Internet broadcasting can allow receiver to & 3.2 & 0.78 & Accepted \\
access broadcast content at their convenience & & &
\end{tabular}

The result from the table above showed that all the items presented in table one two above were accepted as the benefits of the Internet broadcasting to national security.
This is because; all the items had a mean score that range from 2.8-3.6 which is within the acceptable limit of 2.5 for the study.

Table III: Limitations of using Internet broadcasting for national security $(n=363)$

\begin{tabular}{llll}
\hline Item & Mean & SD & Decision \\
\hline Internet broadcasting cannot be accessed by those & 2.6 & 0.84 & Accepted \\
without Internet skills & & & \\
It is cost effective because it requires data & 3.3 & 0.98 & Accepted \\
It requires sophisticated receiving gadget & 3.2 & 0.83 & Accepted \\
Network could pose a challenge & 2.9 & 0.92 & Accepted \\
Powering of gadget could be a limitation & 3.5 & 0.66 & Accepted \\
\hline
\end{tabular}

Source: Field survey, 2016

The result from the table III above showed that all the items presented were accepted as the limitations of using Internet broadcasting for national security in Nigeria. Based on the result, all the items had mean scores that range from 2. 6 to 3.5, which is within the acceptable benchmark for the study.

\section{DISCUSSION OF FINDINGS}

The result of this study showed that most of the respondents $(52 \%)$ reported that Internet broadcasting can promote national security to a large extent. It was also found that the benefits of Internet broadcasting are: It is faster; many people have access to the Internet than Radio/ TV; it can be easily accessed; it has a wider reach and Internet broadcasting can allow receivers to access broadcast content at their convenience.

The result also showed that the limitations of the Internet broadcasting are: the Internet broadcasting cannot be accessed by those without Internet skills; it is cost effective because it requires data; it requires sophisticated receiving gadget; network could pose a challenge and powering of gadget could be a limitation. The result of this study supports the submission of Rohde and Schwarz
(2001) who noted Internet broadcasting has the capacity to reach many receivers than broadcasting through the airwaves.

The result of this study which indicates that people have access to the Internet than radio/television is contrary to a survey conducted by the National Bureau of Statistics (2011) which indicates that only $3.1 \%$ of Nigerians have access to the internet with a negligible $0.5 \%$ claiming ownership of the internet as against while $13 \%$ were found to have access to TV. Although the study could not specify that the Internet access was measured based on sophisticated cell phones with the Internet features or only PC. This is because, in contemporary society, there are many smart mobile phones with Internet features that can allow users to access Internet broadcasting. Some of these owners of smart phones do not have access to television or radio. Furthermore, smart phones are more portable and can be used for some hours when fully charged unlike most television sets that cannot be used without constant power supply.

The result of this study has implications on the Technological determinism theory and the Safe Nigeria Model (2016). With regards to the Technological Determinism 
theory, the result has supported the postulation of McLuhan (1960) who noted that changes in technology are likely to affect changes in the society. This is because, improvements in technology has significantly influenced changes in broadcasting and reception of broadcast services and its use for security operations. With regards to the Safe Nigeria model of Gever, the result shows that for Nigeria to achieve its national security objectives, socio-economic issues like poverty eradication, food security, and health care services must be promoted through Internet broadcasting, since these denominators can positively or negatively impact on national security. Eradicating poverty, for example is not only the responsibility of the government, people could be encouraged through Internet broadcasting to engage in small and medium scale enterprises as means of reducing crime. Internet broadcast could also be an avenue to promote peaceful co-existence, security awareness messages, among others.

\section{CONCLUSION/RECOMMENDATIONS}

Based on the result of this study, the researcher concludes that Internet broadcasting is a viable tool to mobilize citizens to execute programmes, promote peace and sustainable development which ultimately contribute to achieving national security objectives. To effectively achieve this, the researcher makes the following recommendations:

1. The government of the Federal Republic of Nigeria should promote policies and create conducive environment for Internet broadcasting to strive.

2. Broadcast stations that are yet to start streaming on the Internet should hasten the process as doing so could offer them wider reach and engender the propagation of national security among citizens.

3. Further studies should be conducted to determine knowledge and use of the Internet broadcasting among the Internet users in Nigeria.

4. Further researchers should expand to scope of the study to cover more states in Nigeria so as to give room for generalization.

\section{REFERENCES}

AFP, (2016, May 24th). Oil Attacks in Nigeria's South Hit Power, Water Supply. Retrieved from www.dailymail.co.uk/wires/ afp/article-3607403/Oil-attacks-Nigerias-south-hit-power-watersupply.html

Asad, D. (2007). National Affair, Retrieved from http://www.nigeriavillagesquare.com

Asemah, E. S. (2011). Selected Mass Media Themes. Jos: University Press.

Babbie, E. (2010). The Practice of Social Research (12thed). US: Wadsworth Publishing.

Ebeh, J. I. (2015). National Security and National Development A Critique. 4(2), 1-14.

Federal Republic of Nigeria (1999): Constitution of the Federal of Nigeria and Fundamental Rights Enforcement Procedure Rules. Abuja: Federal Republic of Nigeria, 2008.

Gever V. C. (2016). Questioning the Safe School Initiative and Making a Case for a Safe Nigerra Model; The Media as the Nucleus. Sokoto Journal of the Social Sciences. 6(6)1-17.

Gever, V. C. (2014 November, 5-7). The Mass Media and the Challenge of Peace Building Between Farmers and Herdsmen in North Central Nigeria. Paper presented at Keffi international conference on politics between nations: 100 years of security in Nigeria. Nasarawa State University.

Giannakos, M. N. \& Vlamos, P. (2013). Educational Webcasts' Acceptance: Empirical Examination and the Role of Experience. British Journal of Educational Technology. 44 No (1), 125-143.
Human Rights Watch (2014). "Those Terrible Weeks in their Camp" Boko Haram violence against Women and Girls in Northeast Nigeria. Human Rights Watch.

Institute for Peace and Economic (2014). 2014 Global Terrorism Report. Measuring and Understanding the Impact of Terrorism. Retrieved from http://economicsandpeace.org/wp content/uploads/2011/09/Terrorism-Index-Report.pdf.

Internet Live Stat (2016). Retrieved from http://www.webat25. org/news/webfacts.

Leask, L. Clairr, C. \& King, C. (2010). Media Coverage of Health Issues and How to Work More Effectively with Journalists: A Qualitative Study. Public Health, 1-7.

McLuhan, M. (1964). Understanding Media, Routledge, London.

McQuail, D. (2005). Mass communication Theory. London, UK: SAGE Publications.

National Bureau of Statistics, (2011). Annual Socio-economic Report, Access to ICT, Retrieved from www.nigerianstat.gov.ng/ pages/download/35.

Oshio, E. (2009 November, 19th). The Challenge of National Security and Development. Being a paper delivered at the Delta State Christian Professional League Seminar on Crisis Management and Nation Building. Asaba.

Owolabi, T. \& O'neill, E. (2014). Mass Media, Governance and Poverty Reduction Strategy in Nigeria: A Role Evaluation. British Journal of Arts and Social Sciences, 17 (I), 62-74.

Oyebade, A. (2014). Pursuing Human Security through Governance in Nigeria: Agenda for the Next 100 Years. Paper presented at Keffi International Conference on Politics between nations: 100 years of security in Nigeria. Nasarawa State University, Keffi, 5-7 November.

Premium Times (2019, January, 21). Nigeria's internet users hit $111.6 m$ in December - NCC. Retrieved from https://www.premiumtimesng.com/news/more-news/306996-nigerias-internetusers-hit-111-6m-in-december-ncc.html.

Rohde, \& Schwarz (2001). Broadcasting and the Internet: Convergence through New Applications

Westwater, R., Ice, J. and Furht, B. (nd). Multimedia Broadcasting on the Internet. Retrieved from http://webcache.googleusercontent.com/search?q=cache:http://www.cse.fau.edu/ $\sim$ borko/Chapter_MMBroadcasting.pdf.

World Bank (2014). World Development Indicators. Retrieved from http://data.worldbank.org/sites/default/files/wdi-2014book.pdf.

Zerihoun, T. (2016 April, 25). Open Debate of the Security Council on Piracy and Armed Robbery at Sea in the Gulf of Guinea, Assistant Secretary-General," United Nations. Department of Political Affairs. Retrieved from www.un.org/undpa/en/ speechesstatements/25042016/Piracy-Gulf-of-Guinea.

\section{LIST OF REFERENCES LINKS}

AFP, Oil Attacks in Nigeria's South Hit Power, Water Supply. 2016, May 24th. URL: www.dailymail.co.uk/wires/afp/article3607403/Oil-attacks-Nigerias-south-hit-power-water-supply.html (Accessed: 12.08.2019)

Asad D. National Affair, 2007. URL: http://www.nigeriavillagesquare.com (Accessed: 12.08.2019)

Asemah E. S. Selected Mass Media Themes. Jos: University Press, 2011.

Babbie E. The Practice of Social Research (12thed). US: Wadsworth Publishing, 2010.

Ebeh J. I. National Security and National Development. $A$ Critique. 2015. 4(2), pp. 1-14.

Federal Republic of Nigeria (1999): Constitution of the Federal of Nigeria and Fundamental Rights Enforcement Procedure Rules. Abuja: Federal Republic of Nigeria, 2008. 
Gever V. C. Questioning the Safe School Initiative and Making a Case for a Safe Nigerra Model; The Media as the Nucleus. Sokoto Journal of the Social Sciences. 2016. No 6(6), pp. 1-17.

Gever V. C. The Mass Media and the Challenge of Peace Building Between Farmers and Herdsmen in North Central Nigeria. Paper presented at Keffi international conference on politics between nations: 100 years of security in Nigeria. Nasarawa State University. 2014, November. Pp. 5-7.

Giannakos M. N., Vlamos P. Educational Webcasts' Acceptance: Empirical Examination and the Role of Experience. British Journal of Educational Technology. 2013. Issue 44, No (1), pp. 125-143.

Human Rights Watch. "Those Terrible Weeks in their Camp" Boko Haram violence against Women and Girls in Northeast Nigeria. Human Rights Watch, 2014.

Institute for Peace and Economic. 2014. Global Terrorism Report. Measuring and Understanding the Impact of Terrorism. URL: http://economicsandpeace.-org/wp content/uploads/2011/09/ Terrorism-Index-Report.pdf (Accessed 14.11.2018)

Internet Live Stat (2016). http://www.webat25.org/news/ webfacts

Leask L., Clairr C., King C. Media Coverage of Health Issues and How to Work More Effectively with Journalists: A Qualitative Study. Public Health, 2010. Pp. 1-7.

McLuhan M. Understanding Media, Routledge, London, 1964. McQuail D. Mass communication Theory. London, UK: SAGE Publications, 2005.

National Bureau of Statistics. Annual Socio-economic Report, Access to ICT, 2011. URL: www.nigerianstat.gov.ng/pages/ download/35 (12.08.2018).
Oshio E. The Challenge of National Security and Development. Being a paper delivered at the Delta State Christian Professional League Seminar on Crisis Management and Nation Building. Asaba. 2009, November, 19th.

Owolabi T., O'neill E. Mass Media, Governance and Poverty Reduction Strategy in Nigeria: A Role Evaluation. British Journal of Arts and Social Sciences, 2014. Issue 17 (I), pp. 62-74.

Oyebade A. Pursuing Human Security through Governance in Nigeria: Agenda for the Next 100 Years. Paper presented at Keffi International Conference on Politics between nations: 100 years of security in Nigeria. Nasarawa State University, Keffi, 2014. 57 November.

Premium Times Nigeria's internet users hit 111.6m in December - NCC. 2019, January, 21). URL: https://www.premiumtimesng.com/news/more-news/306996-nigerias-internet-users-hit111-6m-in-december-ncc.html (Accessed 04.08.2019).

Rohde \& Schwarz. Broadcasting and the Internet: Convergence through New Applications, 2001.

Westwater R., Ice J. and Furht B. (nd). Multimedia Broadcasting on the Internet. URL: http://webcache.googleusercontent.com/ search?q=cache:http://www.cse.fau.edu/ borko/Chapter_MMBroadcasting.pdf (Accessed 19.08.2018).

World Bank. World Development Indicators. 2014. URL: http:/ /data.worldbank.org/sites/default/files/wdi-2014-book.pdf (Accessed 11.09.2019).

Zerihoun T. Open Debate of the Security Council on Piracy and Armed Robbery at Sea in the Gulf of Guinea, Assistant Secretary-General," United Nations. Department of Political Affairs. 2016, April, 25. URL: www.un.org/undpa/en/speechesstatements/ 25042016/Piracy-Gulf-of-Guinea (Accessed 11.08.2018).

\author{
Амвросій Ігбоке, \\ Університет Нігерії (м. Нсукка, Нігерія) \\ e-mail: ambigon2001@yahoo.com,ORCID 0000-0001-6377-8774
}

\title{
ЗМІЦНЕННЯ НАЦІОНАЛЬНОЇБЕЗПЕКИ ЗА ДОПОМОГОЮ ІНТЕРНЕТ-МОВЛЕННЯ: ПЕРЕВАГИ ТА ОБМЕЖЕННЯ
}

Стаття присвячена оцінці потенціалу інтернет-мовлення для зміцнення системи національної безпеки країни. Актуальність даної проблеми зумовлена безпековими пріоритетами, від яких напряму залежить стійкість політичної системи держави, життя, здоров'я і добробут нації. Свої теоретичні висновки автор робить на підставі емпіричного дослідження, проведеного в трьох регіонах Нігерії. У цієї африканської країни багато проблем, пов'язаних з національною безпекою: релігійні конфлікти, тероризм, бандитизм, викрадення людей, сепаратизм, включаючи Рух за суверенну державу Біафра на південному сході, активність "Боко Харам" на півночі та бойовиків дельти Нігеру, а також голод, зубожіння, комунальні сутички, конфлікти скотарів і фермерів, слабкість федеральної влади, відсутність медичних послуг, безробіття тощо. Основною гіпотезою дослідження є теза про те, що за допомогою інтернет-мовлення можливо суттєво сприяти вирішенню вказаних проблем. Наукові завдання, які виконуються в ході дослідження, стосуються: а) визначення ступеня впливу інтернет-мовлення на зміцнення системи національної безпеки в Нігерії, б) виявлення переваг та в) обмежень використання інтернет-мовлення для вирішення безпекових проблем. Вибірка 3384 респондентів була отримана зі штатів Энугу, Абія и Анамбра за допомогою методу багатоступеневої вибірки. При аналізі даних для дослідження використовували SPSS версії 22, тоді як прості відсотки, середнє та стандартне відхилення використовувались в якості статистичних інструментів. Результат опитування свідчить, що 52 \% респондентів вважає, що інтернет-мовлення може значною мірою сприяти національній безпеці. Серед переваг інтернет-мовлення респонденти назвали швидкість, доступність, ширший обсяг, ніж у телебачення, зручність використання. 3 іншого боку, обмеженням інтернет-мовлення є: відсутність доступу у тих, хто не має навичок роботи в мережі, дороговизна гаджетів, необхідних для підключення, відносно короткий термін живлення гаджетів тощо. Аналізуючи висновки опитування, автор розмірковує про теорію технологічного детермінізму, модель безпечної Нігерії та цілі національної безпеки Нігерії. Висловлюються практичні рекомендації щодо вдосконалення системи національної безпеки Нігерії через створення в країні сприятливого середовища для інтернет-мовлення.

Ключові слова: вигода; обмеження; Інтернет-мовлення; національна безпека; Нігерія.

(C) Ambrose Igboke

Надійшла до редакції: 16.09.2019

Прийнята до друку: 04.10.2019 